\title{
Characterization of a Protein Cofactor That Mediates Protein Kinase A Regulation of the Renal Brush Border Membrane $\mathrm{Na}^{+}-\mathrm{H}^{+}$Exchanger
}

\author{
Edward J. Weinman, Deborah Steplock, Yiping Wang, and Shirish Shenolikar \\ Department of Medicine, University of California at Los Angeles School of Medicine, Department of Veterans Affairs Medical Center, \\ Sepulveda, California 91343
}

\begin{abstract}
Activation of cAMP-dependent protein kinase $A$ inhibits the renal proximal tubule brush border membrane $\mathrm{Na}^{+}-\mathrm{H}^{+}$ exchanger by a process involving participation of a regulatory cofactor (NHE-RF) that is distinct from the transporter itself. Recent studies from this laboratory reported a partial amino acid sequence of this putative cofactor (Weinman, E. J., D. H. Steplock, and S. Shenolikar. 1993. J. Clin. Invest. 92:1781-1786). The present experiments detail the structure of the NHE-RF protein as determined from molecular cloning studies. A codon-biased oligonucleotide probe to a portion of the amino acid sequence of the putative cofactor was used to isolate a 1.9-kb cDNA from a rabbit renal library. The encoded protein is 358 amino acids in length and is rich in proline residues. Search of existing data bases indicates that NHE-RF is a unique protein. Using a reticulocyte lysate, the cDNA translated a product of $\sim 44 \mathrm{kD}$, which was recognized by an affinity-purified polyclonal antibody to NHE-RF. Potential phosphorylation sites for protein kinase $A$ are present. The mRNA for the protein is expressed in kidney, proximal small intestine, and liver. Reverse transcription/PCR studies in the kidney indicate the presence of mRNA for NHE-RF in several distinct nephron segments including the proximal tubule. (J. Clin. Invest. 1995. 95:2143-2149.) Key words: renal electrolyte transport • sodium hydrogen exchange - molecular cloning - cAMP-dependent protein kinase
\end{abstract}

\section{Introduction}

Activation of cAMP-dependent protein kinase A (PKA) ${ }^{1}$ inhibits the activity of the renal brush border membrane (BBM) $\mathrm{Na}^{+}-\mathrm{H}^{+}$exchanger $(1-4)$. In vitro studies involving solubilized membranes and a reconstitution assay have suggested that the inhibitory effect of PKA on the activity of the transporter requires participation of another intermediary protein; a regulatory cofactor (NHE-RF) (5-7). A partial amino acid sequence

Address correspondence to Edward J. Weinman, Chief, Medical Service (111), Sepulveda VHA, 16111 Plummer Street, Sepulveda, CA 91343. Phone: 818-895-9395; FAX: 818-895-9516.

Received for publication 9 September 1994 and in revised form 21 November 1994.

1. Abbreviations used in this paper: $\mathrm{BBM}$, brush border membrane; NHE-RF, regulatory cofactor of $\mathrm{Na}^{+}-\mathrm{H}^{+}$exchanger; PKA, protein kinase A; RT, reverse transcription.

The Journal of Clinical Investigation, Inc.

Volume 95, May 1995, 2143-2149 of this putative cofactor, from which an affinity-purified polyclonal antibody to an artificial peptide representing NHE-RF was developed, has been obtained (7). This antibody immunoprecipitated a single protein from renal brush border membranes and decreased the inhibitory effect of PKA on the activity of the reconstituted $\mathrm{Na}^{+}-\mathrm{H}^{+}$exchanger. The immunoprecipitated product could be renatured and co-reconstituted with other brush border membrane proteins to restore the inhibitory effect of PKA.

The present report details the structure of the NHE-RF protein as determined from molecular cloning studies. In addition, the tissue distribution of the mRNA of the protein in rabbit organs and in the cells of rabbit kidney was examined. The cloning strategy involved use of a codon-biased oligonucleotide probe to a portion of the amino acid sequence of the putative NHE-RF. The probe allowed isolation of a 1.9-kb cDNA from a rabbit renal library. The encoded protein is 358 amino acids in length and is rich in proline residues. The cDNA is unique in nucleotide and predicted amino acid sequence. Potential phosphorylation sites for PKA are present. The mRNA for the protein is expressed in kidney, proximal small intestine, and liver. Reverse transcription/(RT)-PCR studies in the kidney indicate the presence of the mRNA for NHE-RF in several distinct nephron segments including the proximal tubule.

\section{Methods}

An antisense oligonucleotide probe corresponding to amino acids 2-10 of the cyanogen bromide fragment of NHE-RF was used to screen a rabbit kidney library (7). The sequence of the oligonucleotide probe was 5'-GTTGAAICCGTAICCGTTIGGICCCTT-3'. Cloning was performed using an oligo-dT rabbit kidney cDNA library (Stratagene Inc., La Jolla, CA) constructed in the lambda ZAP II vector. The library had an average insert size of $1 \mathbf{k b}$ and underwent one round of amplification before use. The host strain for screening and amplification was XL1Blue Escherichia coli. The cloning strategy followed the manufacturer's recommendations. Initially, $\sim 1$ million recombinants were screened and positive colonies were plaque purified by additional screenings. R408 helper phage was used to excise and circularize the pBluescript SK M13(-) phagmid containing the DNA insert. This derived plasmid was transformed and propogated in XL1-Blue. The plasmid DNA was then extracted for sequencing and restriction analysis using a rapid purification protocol (Qiagen, Inc., Chatsworth, CA). The isolated cDNA was sequenced in both directions using sequential oligonucleotide primers and nested deletions generated from both the $\mathrm{T} 7$ and $\mathrm{T} 3$ ends by ExoIII and S1 nucleases. Nucleotide and amino acid sequence analyses were performed using DNASIS/PROSIS (Hitachi America, Ltd., Brisbane, CA). The GCG software package (Genetics Computer Group, Inc., Madison, WI) was used to perform sequence comparisons and multiple alignments.

Total RNA was extracted using an improved modification of the guanidinium isothiocyanate/acid-phenol method (8). Poly (A) ${ }^{+}$RNA was isolated by absorption to oligo-dT cellulose in a binding buffer containing $0.5 \mathrm{M} \mathrm{NaCl}, 20 \mathrm{mM}$ Tris- $\mathrm{HCl}$ (pH 7.4), $1 \mathrm{mM}$ EDTA, and 
$0.1 \%$ SDS. The column was washed in the same buffer. Poly $(\mathrm{A})^{+}$RNA was eluted from the oligo-dT cellulose with $10 \mathrm{mM}$ Tris- $\mathrm{HCl}$ ( $\mathrm{pH} \mathrm{7.4)}$ and $1 \mathrm{mM}$ EDTA at $65^{\circ} \mathrm{C}$, followed by overnight precipitation at $-20^{\circ} \mathrm{C}$ in a solution containing $1 / 10 \mathrm{vol} 3 \mathrm{M}$ sodium acetate ( $\mathrm{pH} 5.2$ ) and 2.5 vol of absolute ethanol. For Northern RNA hybridization analysis, RNA was separated using $1 \%$ agarose $/ 2.2 \mathrm{M}$ formaldehyde gel electrophoresis and transferred in $3 \mathrm{M} \mathrm{NaCl} / 0.3 \mathrm{M}$ sodium citrate ( $\mathrm{pH} 7.0$ ) to nitrocellulose paper. The blots were baked at $80^{\circ} \mathrm{C}$ for $2 \mathrm{~h}$. Prehybridization was performed in a buffer containing $0.001 \%$ BSA (BSA Fraction V; Sigma Chemical Co., St. Louis, MO), 0.001\% Ficoll (Type 400; Pharmacia LKB Biotechnology, Inc., Piscataway, NJ), $0.001 \%$ polyvinylpyrrolidone, $0.75 \mathrm{M} \mathrm{NaCl}, 0.05 \mathrm{M} \mathrm{NaHPO}_{4}$ (pH 7.0), $1.0 \mathrm{mM}$ EDTA ( $\mathrm{pH} 8.0$ ) supplemented with $0.75 \mathrm{M} \mathrm{NaCl}, 75 \mathrm{mM}$ sodium citrate $(\mathrm{pH}$ $7.0), 0.1 \%$ SDS, $10 \%$ dextran sulfate, and denatured, fragmented salmon sperm DNA $(0.2 \mathrm{mg} / \mathrm{ml})$. Hybridization was performed at $42^{\circ} \mathrm{C}$ using the isolated cDNA or the oligonucleotide probe labeled by the random hexamer priming method using $\alpha-\left[{ }^{32} \mathrm{P}\right] \mathrm{dCTP}$, or end labeled using $\gamma$ $\left[{ }^{32} \mathrm{P}\right]$ ATP. The filters were hybridized for $16 \mathrm{~h}$ at $42^{\circ} \mathrm{C}$. After hybridization, the filters were washed twice for $15 \mathrm{~min}$ at $42^{\circ} \mathrm{C}$ in $5 \times \mathrm{SSC}$ and $0.1 \%$ SDS. The filters were then sequentially washed at room temperature for $15 \mathrm{~min}$ in solutions containing $0.1 \%$ SDS with decreasing concentrations of salt $(2 \times$ SSC, $1 \times$ SSC, $0.5 \times$ SSC, and $0.1 \times$ SSC) until background counts were reduced. The washed filters were exposed to $x$-ray film at $-70^{\circ} \mathrm{C}$ overnight. Loading of the RNA gels was quantitated by ethidium bromide staining and/or hybridization using CDNA probes to actin or glyceraldehyde-3-phosphate dehydrogenase (GAPDH).

In vitro translation studies were performed using a cell-free reticulocyte lysate system following the manufacturer's recommendations (Stratagene Inc.) (9). The lysate media contained $\left[{ }^{35} S\right]$ methionine. The polypeptide product was immunoprecipitated by addition of a PBS solution containing $10 \mathrm{mM} \mathrm{Na}_{2} \mathrm{HPO}_{4} / 1.8 \mathrm{mM} \mathrm{KH}_{2} \mathrm{PO}_{4}$ ( $\mathrm{pH} \mathrm{7.0)}, 137 \mathrm{mM} \mathrm{NaCl}$, $3 \mathrm{mM} \mathrm{KCl}$, and protein A Sepharose beads cross linked to an affinitypurified antipeptide antibody to NHE-RF (7). After rocking for $2 \mathrm{~h}$ at room temperature, the protein A-Sepharose beads (Sigma Chemical Co., St. Louis, MO) were collected by centrifugation and washed four times with PBS. The bound protein was released by heating in SDS sample buffer and resolved by autoradiography of 15\% SDS-PAGE gels.

RT/PCR was performed modified from the protocols of Chen and co-workers and validated initially using rabbit kidney RNA $(10,11)$. To determine the distribution of the mRNA of the regulatory protein in defined nephron segments, the glomerulus, convoluted and straight portions of the proximal tubule, thin and thick ascending limbs of Henle's loop, and cortical and inner medullary collecting ducts were dissected in PBS containing $0.1 \%$ BSA and $10 \mathrm{mM}$ vanadyl ribonucleoside complex. Single defined nephron segments were transferred to RT/ PCR tubes containing PBS using pulled microhematocrit tubes coated with a $0.1 \%$ BSA solution. The nephron segments were washed several times with PBS to remove the vanadyl ribonucleoside complex and resuspended in $7 \mu \mathrm{l}$ of a solution containing $2 \%$ Triton X-100,1 U/ $\mu \mathrm{l}$ RNase inhibitor (Perkin-Elmer Corp., Norwalk, CT), and $5 \mathrm{mM} \mathrm{1,4-}$ DTT. Reverse transcription was performed using the reverse transcription system of Gibco BRL (Gaithersburg, MD) using random primers. The final concentrations were $1 \mathrm{U} / \mu \mathrm{l}$ SuperScript II RT (a cloned Moloney murine leukemia virus reverse transcriptase) (GIBCO-BRL, Gaithersburg, MD), $2.5 \mathrm{mM} \mathrm{MgCl}, 0.5 \mathrm{mM}$ of each dNTP, $12 \mathrm{mM}$ DTT, and $25 \mathrm{ng} / \mu \mathrm{l}$ of primers in $20 \mathrm{mM}$ Tris- $\mathrm{HCl}(\mathrm{pH} 8.4), 50 \mathrm{mM}$ $\mathrm{KCl}, 1 \mu \mathrm{g} / \mathrm{ml} \mathrm{BSA}, 0.35 \times \mathrm{PBS}, 0.35 \mathrm{U} / \mathrm{ml}$ RNase inhibitor, and $0.7 \%$ Triton X-100. Reverse transcriptase was omitted from control tubes. The reaction was performed for $50 \mathrm{~min}$ at $42^{\circ} \mathrm{C}$ and then terminated at $70^{\circ} \mathrm{C}$ for $15 \mathrm{~min}$. Before the addition of the PCR reaction mixture, 2 $\mathrm{U} / \mu \mathrm{l} E$. coli $\mathrm{RNase}$ was added to each tube and incubated for $20 \mathrm{~min}$ at $37^{\circ} \mathrm{C}$. PCR was performed in a solution containing $2.5 \mathrm{mM} \mathrm{MgCl}$, $0.1 \mathrm{mM}$ dNTP, $0.1 \mu \mathrm{M}$ of each specific primer, $0.05 \mathrm{U} / \mu 1$ Taq DNA polymerase, $50 \mathrm{mM} \mathrm{KCl}, 0.1 \mu \mathrm{g} / \mathrm{ml} \mathrm{BSA}, 0.14 \%$ Triton X-100, 0.07× PBS, and $20 \mathrm{mM}$ Tris-HCl (pH 8.4) using a Thermocycler (480; PerkinElmer Cetus Instruments). After denaturation for $3 \mathrm{~min}$ at $94^{\circ} \mathrm{C}$, the



Figure 1. Northern hybridization analysis of rabbit kidney total and poly (A) ${ }^{+}$ RNA using the antisense oligonucleotide probe to amino acids $2-10$ of the cyanogen bromide fragment of NHERF (7). $28 S$ and $18 S$ markers are shown. The size of the mRNA is estimated to be $1.9 \mathrm{~kb}$.

samples were maintained at $80^{\circ} \mathrm{C}$ and the Taq polymerase was added to each tube. The products were amplified using 40 cycles at $95^{\circ} \mathrm{C}$ for $1 \mathrm{~min}$ for melting, and $65^{\circ} \mathrm{C}$ for $3 \mathrm{~min}$ for annealing and extending. At the end of the reaction, the samples were cooled and maintained at $4^{\circ} \mathrm{C}$. $10 \mu \mathrm{l}$ of the PCR product was size fractionated using $2 \%$ NuSieve: $1 \%$ SeaKem agarose gel electrophoresis (FMC Corp., Rockland, ME) in $0.5 \times$ Tris-Borate EDTA electrophoresis buffer and stained with ethidium bromide. For Southern blotting, the PCR product was transferred to nitrocellulose and hybridized with the isolated cDNA multiprimed labeled with $\alpha-\left[{ }^{32} \mathrm{P}\right] \mathrm{dCT}$. The PCR product was excised from the gel and purified using chloroform-phenol extraction and subsequently cloned into pCR II vector using the TA cloning kit (Invitrogen, San Diego, CA). Sequences were determined using a DNA sequencer (373A; Applied Biosystems, Inc., Foster City, CA).

\section{Results}

Fig. 1 is a Northern blot of rabbit renal poly (A) ${ }^{+}$RNA probed with the oligonucleotide probe. The oligonucleotide probe hybridized to a single mRNA of $1.9 \mathrm{~kb}$. The probe was then used to screen a rabbit kidney cDNA library. Initially, 1 million colonies were screened. Three positive colonies were isolated and sequenced. Two isolates contained inserts that proved to be fragments of the largest isolate of $1.9 \mathrm{~kb}$. The complete nucleotide sequence of the 1.9-kb clone is shown in Fig. 2. The longest open reading frame predicts a protein of 358 amino acids in length. There are two regions corresponding to amino acids $19-26$ and amino acids $159-166$ that are 100\% homologous to the sequence of the isolated cyanogen bromide peptide 
Figure 2. Nucleotide and deduced amino acid sequences of the 1.9-kb clone corresponding to NHE-RF. The heavy underlined region corresponding to the first 16 known amino acids determined previously by direct amino acid sequence analysis. The light underline indicates the 8 amino acid repeated sequence. This sequence is registered in GenBank Data Bank, accession number U19815.

used to construct the oligonucleotide probe. The sequence starting at residue 157 and extending to amino acid 172 is $100 \%$ homologous to the amino acid sequence of the cyanogen bromide peptide fragment originally reported (7). As predicted from the cDNA, the sequence of the next seven amino acids contains four "mismatches" compared to the original amino acid sequence. Two of the "errors" were alternate calls near the end of the amino acid sequence determination, a region where confidence in the sequencing is low. Two potential phos- phorylation sites for PKA are predicted. The serine residue at position No. 339 is probably preferred.

Search of computer data banks indicates that the isolated cDNA represents a newly described protein. The predicted molecular mass of the 358-amino acid polypeptide is $\sim 39 \mathrm{kD}$ and is smaller than that estimated by SDS-PAGE (12). To establish that the cDNA encodes the putative regulatory cofactor and to determine the size of the product, translation studies were performed using a cell-free reticulocyte lysate system con- 


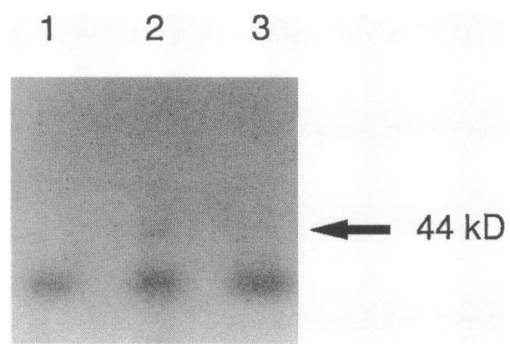


3 represent the $\mathrm{T} 7$ and $\mathrm{T} 3$ promoter elements, respectively.

taining $\left[{ }^{35} \mathrm{~S}\right]$ methionine. The product of the reaction was immunoprecipitated using an affinity-purified polyclonal antibody to an artificial peptide representing the same amino acids used to develop the oligonucleotide probe (7). Fig. 3 is an autoradiograph of the immunoprecipitated ${ }^{35} \mathrm{~S}$ product of the isolated cDNA. The size of the product recognized by the antibody is $>44 \mathrm{kD}$ as estimated by SDS-PAGE and is close to that previously reported (12).

Fig. 4 is a Northern hybridization analysis using poly(A) ${ }^{+}$ RNA from the rabbit kidney cortex. Fig. 5 is a Northern hybridization analysis using total RNA from various tissues of the rabbit. Equal loading of the lanes was verified by ethidium bromide staining and by hybridization using a cDNA probe to GAPDH. The cDNA to NHE-RF hybridized to a single mRNA of $1.9 \mathrm{~kb}$ in the kidney, small intestine, and liver. All other organs tested were negative. RT-PCR was used to determine the nephron distribution of the mRNA of the putative regulatory cofactor. RT-PCR was performed initially using rabbit kidney RNA and oligonucleotide or random primers for reverse transcription. For the PCR reaction, the oligonucleotide sense primer, 5'-GAAGCGCAGCAGCAGACGGGC-3', and antisense primer, 5'-ACTGGAGAATCGGGCGGAGAGG-3', were used. These primers spanned the stop codon region of the CDNA. The RT-PCR product was of the appropriate size of $\sim 121 \mathrm{bp}$; it was hybridized to the isolated cDNA using South-

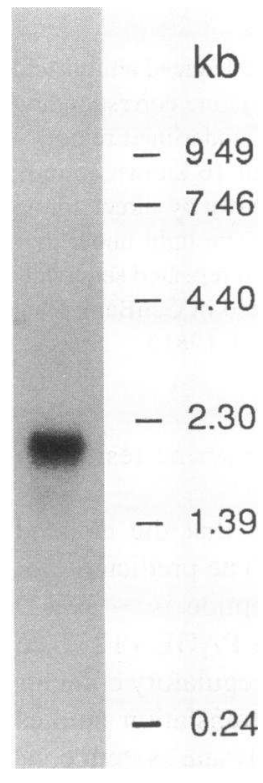

Figure 4. Northern hybridization analysis of rabbit kidney poly $(\mathrm{A})^{+}$RNA using the cloned cDNA as the probe.
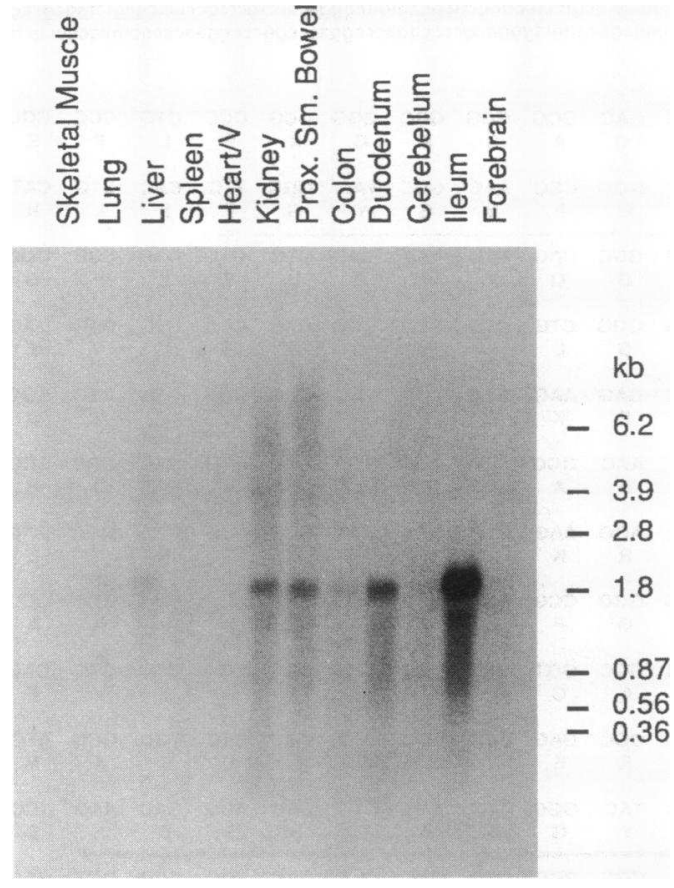

Figure 5. Northern hybridization analysis of RNA from various tissues from the rabbit using the cloned cDNA as the probe.

ern hybridization techniques; and it contained the exact predicted sequence as confirmed by direct analysis. Fig. 6 is an ethidium bromide stain of the RT-PCR product indicating generation of a product of appropriate molecular weight. Also shown is the lack of a product in the absence of RT. For the study of tubules, distinct microdissected tubule segments were pooled for RT-PCR. The product was identified by size and by Southern blotting using the isolated cDNA. Each type of individual dissected nephron segment was studied two or more times in tubules obtained from different animals. As summarized in Table $I$, the mRNA for the regulatory cofactor was detected in the glomerulus; the $S_{1}, S_{2}$, and $S_{3}$ portions of the proximal tubule; the thick ascending limb of Henle's loop; and the cortical collecting duct. It was not detected in the thin descending limb of Henle's loop or the medullary collecting duct. To insure that the failure to detect the mRNA for NHE-RF in the thin descending limb and in the medullary collecting duct was not the consequence of technical considerations, RT-PCR was performed in these nephron segments using primers to GAPDH. A product of appropriate size was detected in both nephron segments (data not shown).

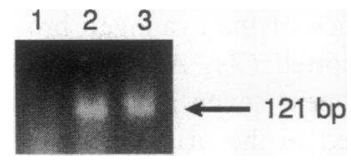

Figure 6. Representative agarose gel of RT-PCR product of NHE-RF using rabbit kidney RNA. The results in the absence (lane 1 ) or presence (lane 2 ) of reverse transcriptase are shown. Lane 3 is the $S_{1}$ segment of the proximal convoluted tubule as a representative example of the product obtained from tubules containing the mRNA for NHE-RF. 
Table I. Detection of mRNA for NHE-RF in Nephron Segments of the Rabbit Nephron Using RT-PCR

\begin{tabular}{ll}
\hline \multicolumn{1}{c}{ Nephron segment } & NHE-RF mRNA \\
\hline Glomerulus & Detected \\
Proximal tubule-S $S_{1}$ & Detected \\
Proximal tubule-S & Detected \\
Proximal tubule-S $S_{3}$ & Detected \\
Thin descending limb $\cdots$ & Not detected \\
Thick ascending limb & Detected \\
Cortical collecting duct & Detected \\
Medullary collecting duct & Not detected \\
\hline
\end{tabular}

\section{Discussion}

As summarized in the introduction and in recent publications from this laboratory, the inhibitory effect of PKA on the renal brush border $\mathrm{Na}^{+}-\mathrm{H}^{+}$exchanger appears to involve participation of an additional protein cofactor $(13,14)$. This cofactor, named NHE-RF, is a thermolabile, trypsin-sensitive substrate for PKA that is distinct and dissociable from the $\mathrm{Na}^{+}-\mathrm{H}^{+}$ exchange transporter itself. In prior studies from this laboratory, NHE-RF had been purified using column chromatography, and a partial amino acid sequence was obtained (7). This amino acid sequence information permitted construction of an oligonucleotide probe, biased toward codon usage in the rabbit, and containing four inosines in the highly variant third base positions. The oligonucleotide probe identified a single mRNA in rabbit kidney cortex using Northern hybridization analysis. Screening of a rabbit kidney cDNA library with the oligonucleotide probe resulted in isolation of a 1.9-kb cDNA. Computer search of existing data bases indicated that the cDNA encodes a protein not previously described.

The finding that size of the mRNA and the cloned cDNA were the same suggests that a full-length clone was isolated. The cDNA encodes a protein consisting of 358 amino acids with a calculated molecular mass of $38.6 \mathrm{kD}$. This predicted size is less than that suggested from prior studies using column chromatography and autoradiography of SDS-PAGE gels containing the cofactor phosphorylated by PKA $(4-7,12)$. To clarify this issue, cell-free translation studies were performed. These experiments indicated that the cDNA encodes a single protein recognized by the affinity-purified polyclonal antibody to the protein with an apparent molecular mass of $44 \mathrm{kD}$ as determined by slab gel electrophoresis. This estimated size is more consistent with that determined previously (12). Translation of the cDNA indicates that there are relatively few hydrophobic residues. There is a single tryptophan, three tyrosine, and nine phenylalanine residues. By contrast, the protein is relatively enriched in charged residues, with 55 acidic and 48 basic amino acids. The predicted amino acid sequence of NHERF indicates a sequence, residues $160-181$, closely following a methionine at position 157 that matched precisely the $\mathrm{NH}_{2}$ terminal sequence obtained from the purified cyanogen bromide peptide fragment of NHE-RF (7). This finding confirms that the appropriate cDNA had been isolated. Further analysis of this amino acid sequence identified a second sequence, residues $21-42$, that shared $75 \%$ identity with the $\mathrm{NH}_{2}$-terminal peptide

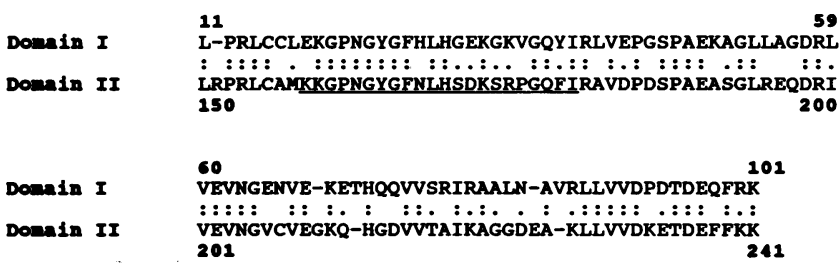

Figure 7. Comparison of the predicted amino acid sequences of the NHE-RF cDNA indicating homology between amino acids 11-101 (Domain I) and amino acids 150-241 (Domain II).

sequence of the 31-kD phosphopeptide that was used to develop the oligonucleotide probe and the antipeptide antibody described in this and prior studies (7). In fact, the homologous sequence exceeded the 21 amino acids that were sequenced (Fig. 7). The two domains encompassed by the residues 11101 and $150-241$ showed $74 \%$ overall homology suggesting duplication of this domain. The homology between these domains predicts considerable conservation of the secondary structure of domains I and II. Collectively, domains I and II make up nearly $70 \%$ of the NHE-RF protein (Fig. 8).

The extreme COOH-terminal sequence of NHE-RF that extends beyond domain II contains the majority of the serine and threonine residues and may include the sites phosphorylated by PKA. The optimal consensus motif for PKA has been defined as $\mathrm{RR} / \mathrm{KXYS} * \mathrm{H}$, where * indicates the phosphorylated serine residue (15). In the NHE-RF protein, only two serine residues and none of the threonine residues are preceded by $\mathrm{NH}_{2}$-terminal basic residues that are essential determinants for substrate phosphorylation by PKA. This is consistent with the suggestion that NHE-RF is phosphorylated by PKA exclusively on serine residues. However, since there is only one basic residue preceding each of the two serines, neither of the two potential phosphorylation sites appears to represent an idealized substrate for PKA. The predicted NHE-RF protein sequence contained three methionines at positions 1,157 , and 346. This information provided an explanation for the observation that cyanogen bromide cleavage of the native NHE-RF resulted in only two major peptide fragments, of apparent molecular mass $21 \mathrm{kD}$ and 31 $\mathrm{kD}$. The $21-\mathrm{kD}$ cyanogen bromide peptide obtained by hydrolysis of the PKA-phosphorylated NHE-RF contained no $\left[{ }^{32} \mathrm{P}\right]-$ phosphate, and repeated efforts to sequence this $\mathrm{NH}_{2}$-terminal peptide were unsuccessful. Attempts to determine the $\mathrm{NH}_{2}$-terminal sequence of the intact NHE-RF protein were also unsuccessful. These results are consistent with the location of this 21-kD cyanogen bromide peptide fragment at the $\mathrm{NH}_{2}$-terminal end of NHE-RF. The failure to obtain amino acid sequences

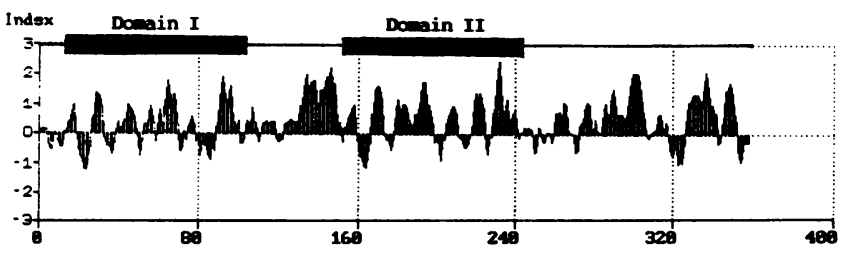

Figure 8. Hydropathy analysis of NHE-RF indicating homologous domains. 
from either parent NHE-RF protein or the $21-\mathrm{kD}$ peptide fragment suggests also that they shared a blocked $\mathrm{NH}_{2}$-terminal end. It is likely that the $21-\mathrm{kD}$ peptide represents the primary sequence between residues 2 and 157 . By contrast, the $31-\mathrm{kD}$ peptide contained all the $\left[{ }^{32} \mathrm{P}\right]$ phosphate incorporated into NHE-RF by PKA and probably represents a more COOH-terminal fragment between residues 158 and 346 in the NHE-RF protein.

Northern blot hybridization analysis was used to determine the size of the mRNA and its tissue distribution. The cDNA identified a single message in rabbit kidney of a size identical to that seen using the oligonucleotide probe. A message of the same size was identified also in small intestine. Western immunoblot analysis of rabbit renal and small intestinal brush border membranes using an antibody to NHE-RF identified a protein of the same molecular weight in both tissues (7). As determined immunologically, protein expression per milligram of total protein was somewhat greater in the small intestine than kidney. These results appear consistent with the greater abundance of the mRNA for NHE-RF in small intestine as compared to kidney. It is of interest that liver contained significant amounts of NHE-RF mRNA. The significance of this finding is unknown.

RT-PCR was used to identify more precisely the nephron segments that expressed the mRNA for the regulatory cofactor. These experiments were important since prior efforts using the antipeptide antibody and immunocytochemistry to localize the protein to specific cells in the kidney were unsuccessful. The RT-PCR procedure was validated using total RNA from kidney. The RT-PCR product was of the correct predicted size, hybridized to the cloned cDNA using Southern blotting procedures, and was the precise nucleotide sequence encompassed by the PCR primers. The RT-PCR product from tubule segments was of the same size as that obtained using total rabbit kidney RNA, and the identity of this product was confirmed by Southern hybridization with the cloned cDNA. By this analysis, the glomerulus, the proximal tubule, the thick ascending limb, and the cortical collecting duct contained NHE-RF mRNA. No RT-PCR product was found in the thin descending limb or medullary collecting duct.

Hydropathy analysis gives no indication of transmembrane structures in the NHE-RF protein (Fig. 8). This predicted structure correlates well with Western immunoblot studies that indicate the presence of the protein in BBM preparations from rabbit kidney, rabbit small intestine, $\mathrm{LLCPK}_{1}$ cells, and in the plasma membrane of OK cells (7). In all these tissues, the protein was detected also in significant abundance in the cytosolic fraction. As NHE-RF exists in both soluble and membrane-bound forms, it could be speculated that, in addition to its phosphorylation by PKA, the distribution of this cofactor within the cell may play a role in hormonal control of $\mathrm{Na}^{+}-\mathrm{H}^{+}$exchange. Moreover, the duplicated domains may represent sites of interaction of NHE-RF with the transmembrane protein that represents the antiporter. Selective deletion of each of these domains and potential sites of phosphorylation by PKA will help to define the functional role of individual structural elements in the control of $\mathrm{Na}^{+}-\mathrm{H}^{+}$exchange activity.

The present studies define the structure of a unique protein expressed in tissues that have $\mathrm{Na}^{+}-\mathrm{H}^{+}$exchange activity that is inhibited by cAMP. To date, the evidence that indicates that NHE-RF is required for expression of the inhibitory effect of
PKA on the $\mathrm{Na}^{+}-\mathrm{H}^{+}$exchanger derives solely from in vitro studies using BBM from the kidney of rabbit (5-7). Recently, Levine et al. transfected PS120 cells, Chinese hamster lung fibroblast cells lacking endogenous $\mathrm{Na}^{+}-\mathrm{H}^{+}$exchange activity, with either NHE-1, NHE-2, or NHE-3. The transfected cells displayed $\mathrm{Na}^{+}-\mathrm{H}^{+}$exchange activity as determined by a functional assay but did not demonstrate regulation of $\mathrm{Na}^{+}-\mathrm{H}^{+}$ exchange activity by cAMP (16). These experiments would appear to indicate that none of the three isoforms tested is regulated by PKA under the conditions of study. Although metabolic labeling and increased incorporation of $\left[{ }^{32} \mathrm{P}\right]$ phosphate into expressed NHE proteins following cAMP stimulation was not examined, these results are consistent with the hypothesis that PKA regulation of the BBM exchanger requires a regulatory cofactor distinct from the exchanger itself. Preliminary studies in our laboratory using Western immunoblot analysis indicate that PS120 cells do not contain the putative regulatory protein. This may provide an explanation for the inability of PKA to regulate the activity of the transfected NHE isoforms. By contrast, Yamaji et al. have reported in abstract form the expression of NHE-3 in xenopus oocytes (17). In this expression system, cAMP did inhibit $\mathrm{Na}^{+}-\mathrm{H}^{+}$exchange activity. This predicts that amphibian oocytes contain a regulatory factor that is functionally similar to NHE-RF. It is also possible that PKA affects the activity of the $\mathrm{Na}^{+}-\mathrm{H}^{+}$exchange activity in oocytes by a mechanism different from that identified in rabbit kidney proximal tubule cells (14). The expression of recombinant NHE-RF protein should facilitate future studies examining the expression of this protein in other cells and species as well as establishing the physiologic role of NHE-RF in mammalian cells.

\section{Acknowledgments}

The authors acknowledge the expert assistance of Hilda Chamras, Ph.D., and Dr. N. Yanagawa of the Department of Medicine, UCLA/San Fernando Valley Program. The helpful advice of Dr. Richard Weisbart and Dr. Samuel Murray, Department of Medicine, UCLA/San Fernando Valley Program, and David Woo, Division of Nephrology, UCLA, is acknowledged.

This work was supported by grants from the National Institutes of Health, DK-37319, and the Research Service of the Department of Veterans Affairs.

\section{References}

1. Kahn, A. M., G. M. Dolson, M. K. Hise, S. C. Bennett, and E. J. Weinman. 1985. Parathyroid hormone and dibutyryl cyclic AMP inhibit $\mathrm{Na}^{+}-\mathrm{H}^{+}$countertransport in brush border membrane vesicles isolated from a suspension of rabbit proximal tubules. Am. J. Physiol. 248(Renal Fluid Electrolyte Physiol. 17):F212F218.

2. Dolson, G. M., M. K. Hise, and E. J. Weinman. 1985. Relationship among parathyroid hormone, CAMP, and calcium on proximal tubule sodium transport. Am. J. Physiol. 249(Renal Fluid Electrolyte Physiol. 18):F409-F416.

3. Weinman, E. J., S. Shenolikar, and A. M. Kahn. 1987. CAMP-associated inhibition of $\mathrm{Na}^{+}-\mathrm{H}^{+}$exchanger in rabbit kidney brush-border membranes. Am. J. Physiol. 252(Renal Fluid Electrolyte Physiol. 21):F19-F25.

4. Weinman, E. J., W. P. Dubinsky, and S. Shenolikar. 1988. Reconstitution of cAMP-dependent protein kinase regulated renal $\mathrm{Na}^{+}-\mathrm{H}^{+}$exchanger. J. Membr. Biol. 101:11-18.

5. Weinman, E. J., W. P. Dubinsky, Q. Dinh, D. Steplock, and S. Shenolikar. 1989. The effect of limited trypsin digestion on the renal $\mathrm{Na}^{+}-\mathrm{H}^{+}$exchanger and its regulation by CAMP dependent protein kinase. J. Membr. Biol. 109:233-241.

6. Weinman, E. J., D. Steplock, G. Bui, N. Yuan, and S. Shenolikar. 1990. Regulation of the renal $\mathrm{Na}^{+}-\mathrm{H}^{+}$exchanger by CAMP dependent protein kinase. Am. J. Physiol. 258(Renal Fluid Electrolyte Physiol. 27):F1254-F1258. 
7. Weinman, E. J., D. Steplock, and S. Shenolikar. 1993. CAMP-mediated inhibition of the renal brush border membrane $\mathrm{Na}^{+}-\mathrm{H}^{+}$exchanger requires a dissociable phosphoprotein cofactor. J. Clin. Invest. 92:1781-1786.

8. Chirgwin, J. M., A. E. Przybyla, R. J. MacDonald, and W. J. Rutter 1979. Isolation of biologically active ribonucleic acid from sources enriched in ribonuclease. Biochemistry. 18:5294-5299.

9. Rothman, R. E., D. W. Andrews, M. C. Calayag, and V. R. Lingappa 1993. Construction of defined polytopic integral transmembrane proteins. J. Biol. Chem. 268:17-20.

10. Chen, D., V. Magnuson, S. Hill, C. Arnaud, B. Steffensen, and R. J. Klebe. 1992. Regulation of integrin gene expression by substrate adherence. $J$. Biol. Chem. 267:23502-23506.

11. Chen, D., V. L. Magnuson, B. Steffensen, and R. J. Klebe. 1993. Use of stock solutions to simplify mRNA quantitation by reverse transcription PCR assays. PCR Meth. Applications. 2:351-353.

12. Morell, G., D. Steplock, S. Shenolikar, and E. J. Weinman. 1990. Identification of a putative $\mathrm{Na}^{+}-\mathrm{H}^{+}$exchanger regulatory co-factor in rabbit renal apical membranes. Am. J. Physiol. 259(Renal Fluid Electrolyte Physiol. 28):F867F871.

13. Weinman, E. J., W. Dubinsky, and S. Shenolikar. 1989. Regulation of the renal $\mathrm{Na}^{+}-\mathrm{H}^{+}$exchanger by protein phosphorylation. Kidney Int. 36:519-525.

14. Weinman, E. J., and S. Shenolikar. 1993. Regulation of the renal brush border membrane $\mathrm{Na}^{+}-\mathrm{H}^{+}$exchanger. Annu. Rev. Physiol. 55:289-304.

15. Adams, J. A., and S. S. Taylor. 1993. Phosphorylation of peptide substrates for the substrates for the catalytic subunit of cAMP-dependent protein kinase. $J$. Biol. Chem. 268:7747-7752.

16. Levine, S. A., M. H. Marshall, C. M. Tse, and M. Donowitz. 1993. Kinetics and regulation of three cloned mammalian $\mathrm{Na}^{+} / \mathrm{H}^{+}$exchangers stably expressed in a fibroblast cell line. J. Biol. Chem. 268:25527-25535.

17. Yamaji, Y., M. Amemiya, R. J. Alpern, and O. W. Moe. 1993. Protein kinase A (PKA) and a calcium independent protein kinase phosphorylate the cytoplasmic domain of $\mathrm{Na} / \mathrm{H}$ exchanger-3 (NHE-3) in vitro. J. Am. Soc. Nephrol. 24:851. (Abstr.). 